\title{
Editorial: Improving Care and Outcome through NMAHP Research-Focused Clinical Academic Roles - An International Perspective
}

A warm welcome to this special issue of the International Journal of Practice-based Learning in Health and Social Care. We are delighted to share with you the current United Kingdom and international landscape regarding nursing, midwifery and allied health professionals (NMAHPs) research-focused clinical academic roles.

Research-active healthcare provider organisations have improved patient outcomes compared to nonresearch active organisations (Care Quality Commission, 2018). NMAHPs make a valuable contribution towards this research activity, particularly in terms of the patient experience, and more increasingly in regard to diagnosis and treatment. While we make particular reference to nurses, midwives, and allied health professionals within this special issue, the articles and learning are relevant to other healthcare professional groups including psychologists, pharmacists, and scientists.

The NMAHP research-focused clinical academic is a relatively new concept. Australia has a twenty-year history of developing and supporting NMAHP clinical academic roles. Despite this, there is controversy regarding the focus and value of the role (see Carrick-Sen et al., 2019 in this special issue). The United States has established the role of the clinical professor for over a decade; however, clinical professors lack an established career and/or training pathway at junior or mid-career level. Within the United Kingdom, the first notion of a NMAHP clinical academic is reported in psychology in 1970 (Thelen \& Ewing, 1970), followed by nursing in 1977 (Hicks \& Westphal, 1977). During the 1980s, a related but different role became established: the clinical research nurse, focused on research delivery, particularly clinical trials (Cronenwett, 1986; McGillick \& Fernandes, 1980). Outside the United Kingdom, the first notion of a NMAHP clinical academic is reported in Canada in 1987 (Acorn, 1987). Since then - and of particular note - from the 1990s onwards, there has been increasing recognition of the role of the NMAHP clinical academic as well as increased understanding of the differences to the clinical research role (Bender et al., 2019; Butterworth, 2005; Cassidy \& Macfarlane, 1991).

Although there is a general understanding of the term 'clinical academic', the notion of research capacity building is not new (DeFriese \& Seipp, 1978; Good, 1992; Habte, 1992). There is an increasing number of strategies, models, and measurement tools available (Bethune et al., 2019; Johnson, 2019; Sabey et al., 2019). Two articles in this special issue (Iles-Smith et al. 2019; Iles-Smith \& Ersser, 2019) describe novel approaches that can facilitate discussion and increased research activity during the professional development review. Furthermore, a number of articles within this special issue allude to a desire and need to combine research activity within the clinical NMAHP role to further develop evidence-based

Special Issue Editors' Contact details:

Professor Emerita Debbie Carrick-Sen, PhD, MSc, PGCE, RGN, RM Professor Emerita of Nursing and Midwifery, University of Birmingham, $U K$. Email: d.carrick-Sen@bham.ac.uk Professor Emerita Ann Moore, CBE, PhD, MCSP, MACP, Cert.Ed., Dip.TP, FHEA, FCSP, FMACP, D.Sc (Honorary) Professor Emeritus of Physiotherapy, University of Brighton,UK. Email: a.p.moore@brighton.ac.uk

Journal URL: https://publications.coventry.ac.uk/index.php/pblh

Carrick-Sen, D. M., \& Moore, A. P. (2019). Editorial: Improving care and outcome through NMAHP research-focused clinical academic roles - An international perspective. International Journal of Practice-based Learning in Health and Social Care, 7(2), ii-vi. DOI 10.18552/ijpblhsc.v7i2.648

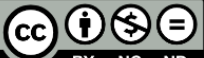

BY NC ND (C) 2019 Debbie Carrick-Sen and Ann Moore. This Open Access article is distributed under the terms of the Creative Commons Attribution Attribution-Non-Commercial No Derivatives 4.0 International License (https://creativecommons.org/licenses/by-nc-nd/4.0/ ), which permits unrestricted non-commercial use, distribution, and reproduction in any medium, provided the original work is properly cited and is unaltered. 
practice and innovation to improve treatment, patient experience, and clinical outcome (see Cooper et al., 2019 in this special issue). A successful, interesting yet practical approach suggests using robust researchbased service improvement methodology to improve professional practice and care outcomes (see Bell \& Colleran, 2019 in this special issue). Defining metrics including key performance indicators (KPIs) is fundamental when establishing new roles. It is therefore critical that research and clinical KPIs are agreed and monitored by all key stakeholders (see Coad et al., 2019 in this special issue). There is a substantial link between robust service improvement methodology and research activity. Should the terminology of service improvement be more acceptable to senior clinical managers and leaders, then maybe it is timely and necessary to review the concept and scope of research activity within the clinical healthcare setting.

Recruitment and retention of high-quality staff is a global issue (Kelly \& Fowler, 2019; O'Brien \& Ackroyd, 2012; Yeager \& Wisniewski, 2017). There are emerging links between workforce satisfaction, role autonomy, and retention of high-quality staff (Bakker et al., 2010; Bartram et al., 2004; Cameron et al., 2004; Hayne et al., 2009). Investment in professional development, and encouraging staff to work at the top of the licence, contribute to high-level role satisfaction, empowerment, and autonomy (Nedd, 2006). Therefore, developing and supporting NMAHP clinical academic roles are likely to contribute to the recruitment and retention of high-quality staff. There are additional organisation benefits, including increased income and innovative reputation (see Cooper et al., 2019 in this special issue).

Within the United Kingdom, the Clinical Academic Roles Implementation Network (CARIN) was established in 2017 under the Council of Deans for Health

(https://councilofdeans.org.uk/category/policy/research/clinical-academic-roles-implementationnetwork/). The network is free to join, and members include nominated leads from healthcare provider organisations as well as a number of senior clinical academic facilitators. The purpose of the network is to guide and support United Kingdom healthcare organisations to develop and sustain NMAHP clinical academic roles. An additional purpose is to facilitate and share innovation and success as well as challenges. The articles within this special issue detail a number of innovations (for example, see Bell \& Colleran, 2019; Iles-Smith et al., 2019; Iles-Smith \& Ersser, 2019) that contribute to success in developing and sustaining NMAHP clinical academic roles.

As well as benefits to an organisation, additional benefits may accrue to the individual in terms of career progression, academic attainment, as well as making a valuable contribution to science - and therefore to the evidence base. The use of case studies as a methodology is particularly useful in capturing the benefits gained to individuals (see Hiley et al., 2019 and Cooper et al., 2019 in this special issue), organisations (Carrick-Sen et al., 2016), the profession, and of course in terms of improved patient outcomes. In summary, patients, organisations, and healthcare professionals all benefit from the development of increased research activity through clinical academic roles. If this is so good, then why isn't everyone doing it?

Despite the rapid growth of clinical academic research roles in the United Kingdom and investment globally (see Carrick-Sen et al., 2019 in this special issue) a number of challenges continue to exist. Professor Alison Richardson, on behalf of Health Education England (HEE) in 2019, wrote a compelling report concerning enablers and barriers to implement clinical academic roles (Richardson et al., 2019). Despite increased understanding of the need and desire to develop the role, to do so requires investment, understanding, executive board engagement, and middle manager support as well as successful partnership-working with external agencies (for example, funders and higher education institutions). In this special issue, the focus is to highlight the ingredients that contribute to success, notwithstanding and accepting the challenges that remain. We hope that you enjoy reading this exciting collection of articles, and that they may stimulate you and your organisation to increase research capability and capacity through clinical academic roles.

\section{Debbie Carrick-Sen and Ann Moore, Special Issue Editors}

\section{ORCID}

Debbie Carrick-Sen: $\quad$ https://orcid.org/0000-0002-2903-8649

Ann Moore: $\quad$ https://orcid.org/0000-0001-7627-3492.




\section{References}

Acorn, S. (1987). Joint academic/clinical appointments: A Canadian perspective. AARN News Letter, 43(9), 27-29.

Bakker, D., Butler, L., Fitch, M., Green, E., Olson, K., \& Cummings, G. (2010). Canadian cancer nurses' views on recruitment and retention. Journal of Nursing Management, 18(2), 205-214. https://doi.org/10.1111/j.1365-2834.2009.01029.x

Bartram, T., Joiner, T. A., \& Stanton, P. (2004). Factors affecting the job stress and job satisfaction of Australian nurses: Implications for recruitment and retention. Contemporary Nurse, 17(3), 293304. https://doi.org/10.5172/conu.17.3.293

Bell, C., \& Colleran, V. (2019). Empowering Nurses, Midwives and Allied Health Professionals to Gain an Academic, Research and Quality Improvement Experience within Clinical Practice. International Journal of Practice-Based Learning in Health and Social Care, 7(2), 69-79. https://doi.org/https://doi.org/10.18552/ijpblhsc.v7i2.641

Bender, M., Baker, P., Harris, J. L., Hites, L., LaPointe, R. J., Murphy, E. A., Roussel, L., Spiva, L.A., Stanley, J. M., Thomas, P. L., Williams, M. (2019). Advancing the clinical nurse leader model through academic-practice-policy partnership. Nursing Outlook, 67(4), 345-353. https://doi.org/10.1016/j.outlook.2019.02.007

Bethune, C., Heeley, T., Graham, W., \& Asghari, S. (2019). There is no "I" in rural research capacity building. Australian Journal of Rural Health, 27(3), 268. https://doi.org/10.1111/ajr.12506

Butterworth, T. (2005). Clinical academic careers for nurses: Time for a renewed debate. Nursing Inquiry, 12(3), 161. https://doi.org/10.1111/j.1440-1800.2005.00278.x

Cameron, S., Armstrong-Stassen, M., Bergeron, S., \& Out, J. (2004). Recruitment and retention of nurses: Challenges facing hospital and community employers. Nursing Leadership, 17(3), 79-92. https://doi.org/10.12927/cjnl.2004.16359

Care Quality Commission (2018). The state of health care and adult social care in England 2017/18. https://www.cqc.org.uk/sites/default/files/20171011_stateofcare1718_report.pdf

Carrick-Sen, D., Moore, A., Davidson, P., Gendong, H., \& Jackson, D. (2019). International Perspectives of Nurses, Midwives and Allied Health Professionals Clinical Academic Roles: Are We at Tipping Point?. International Journal of Practice-Based Learning in Health and Social Care, 7(2), 1-15. https://doi.org/https://doi.org/10.18552/ijpblhsc.v7i2.639

Carrick-Sen, D., Richardson, A., Moore, A., \& Dolan, S. (2016). Transforming healthcare through clinical academic roles in nursing, midwifery and allied health professions: A practical resource for healthcare provider organisations. . https://councilofdeans.org.uk/wpcontent/uploads/2019/02/AUKUH-Transforming-Healthcare.pdf

Cassidy, J., \& Macfarlane, D. K. (1991). The role of the nurse in clinical cancer research. Cancer Nursing, 14(3), 124-131. https://doi.org/10.1097/00002820-199106000-00002

Coad, J., Manning, J., Mills, E., Semple, C., Johnston, B., \& McMahon, A. (2019). Capturing the Real Impact of Clinical Academics in Practice. International Journal of Practice-Based Learning in Health and Social Care, 7(2), 47-56. https://doi.org/https://doi.org/10.18552/ijpblhsc.v7i2.647

Cooper, J., Mitchell, K., Richardson, A., \& Bramley, L. (2019). Developing the Role of the Clinical Academic Nurse, Midwife and Allied Health Professional in Healthcare Organisations. 
International Journal of Practice-Based Learning in Health and Social Care, 7(2), 16-24. https://doi.org/https://doi.org/10.18552/ijpblhsc.v7i2.637

Cronenwett, L. R. (1986). The research role of the clinical nurse specialist. Journal of Nursing Administration, 16(4), 10-11.

DeFriese, G. H., \& Seipp, C. (1978). Building a national capacity for health services research. Health Services Research, 13(3), 238-242.

Good, M.-J. (1992). Local knowledge: Research capacity building in international health. Social Science \& Medicine, 35(11), 1359-1367. https://doi.org/10.1016/0277-9536(92)90039-S

Habte, D. (1992). Building and strengthening research capacity in health: The challenge to Africa. Journal of Diarrhoeal Diseases Research, 10(2), 73-78.

Hayne, A. N., Gerhardt, C., \& Davis, J. (2009). Filipino nurses in the United States: Recruitment, retention, occupational stress, and job satisfaction. Journal of Transcultural Nursing, 20(3), 313-322. https://doi.org/10.1177/1043659609334927

Hicks, B. C., \& Westphal, M. (1977). Integration of clinical and academic nursing at the hospital clinical unit level. Journal of Nursing Education, 16(4), 6-9.

Hiley. J., Jerwood, J., Price, J., Thomas, S., \& Kenkre, J. (2019). Combining a career in clinical practice and research: The benefits at junior career level. International Journal of Practice-based Learning in Health and Social Care, 7(2), 36-45. DOI 10.18552/ijpblhsc.v7i2.638

Iles-Smith, H., Burnette, C., Ross, D., \& Siddle, H. (2019). The Clinicians' Skills, Capability, and Organisational Research Readiness (SCORR) Tool. International Journal of Practice-Based Learning in Health and Social Care, 7(2), 57-68. https://doi.org/https://doi.org/10.18552/ijpblhsc.v7i2.644

Iles-Smith, H., \& Ersser, S. (2019). The DINARC@ Toolkit - Clinical Academic Research CapacityBuilding and Post-Doctoral Development for Nurses, Midwives and Allied Health Professionals (NMAHP). International Journal of Practice-Based Learning in Health and Social Care, 7(2), 25-35. https://doi.org/https://doi.org/10.18552/ijpblhsc.v7i2.645

Johnson, S. L. (2019). Impact, growth, capacity-building of mixed methods research in the health sciences. American Journal of Pharmaceutical Education, 83(2), 7403. https://www.ajpe.org/doi/full/10.5688/ajpe7403

Kelly, S., \& Fowler, C. (2019). Enhancing the recruitment and retention of overseas nurses from Kerala, India. Nursing Standard, 34(5), 25-30. https://doi.org/10.7748/ns.2018.e11071

McGillick, K. J., \& Fernandes, R. (1980). The role of the nurse clinical research associate in testing a new drug. Nursing Forum, 19(4), 378-384. https://doi.org/10.1111/j.1744-6198.1980.tb00727.x

Nedd, N. (2006). Perceptions of empowerment and intent to stay. Nursing Economics, 24(1), 13-18, 13.

O'Brien, T., \& Ackroyd, S. (2012). Understanding the recruitment and retention of overseas nurses: Realist case study research in National Health Service Hospitals in the UK. Nursing Inquiry, 19(1), 39-50. https://doi.org/10.1111/j.1440-1800.2011.00572.x

Richardson, A., Avery, M., \& Westwood, G. (2019). A cross-funder survey of enablers and barriers to progressing a research-related academic career in the non-medical health professions. https://cdn.southampton.ac.uk/assets/imported/transforms/content- 
block/UsefulDownloads_Download/954F8F73B2ED47C8BE68DC29D2359507/Cross\%20Fund er\%20Survey\%20Summary\%20Document \%20April\%202019.pdf

Sabey, A., Bray, I., \& Gray, S. (2019). Building capacity to use and undertake applied health research: Establishing a training programme for the health workforce in the West of England. Public Health, 167, 62-69. https://doi.org/10.1016/j.puhe.2018.11.001

Thelen, M. H., \& Ewing, D. R. (1970). Roles, functions, and training in clinical psychology: A survey of academic clinicians. American Psychologist, 25(6), 550-554. https://doi.org/10.1037/h0029483

Yeager, V. A., \& Wisniewski, J. M. (2017). Factors that influence the recruitment and retention of nurses in public health agencies. Public Health Reports, 132(5), 556-562.

https://doi.org/10.1177/0033354917719704 